\title{
Legal Considerations concerning Youth Street Groups in TRANSGANG Regions
}

José Sánchez-García (Scientific Coordinator),

Andrés García-Berrio (Legal Advisor), Adam Brisley, Maria-Jose Masanet (UPF

Researchers), Paolo Grassi, Juan Camilo Mansilla, Fulvia Márquez, Ligia Lavielle,

Candy Chévez, Rachid Touhtouh, Sihem Najjar, Beladaci Larbi (Local Researchers)

Carles Feixa (Principal Investigator).

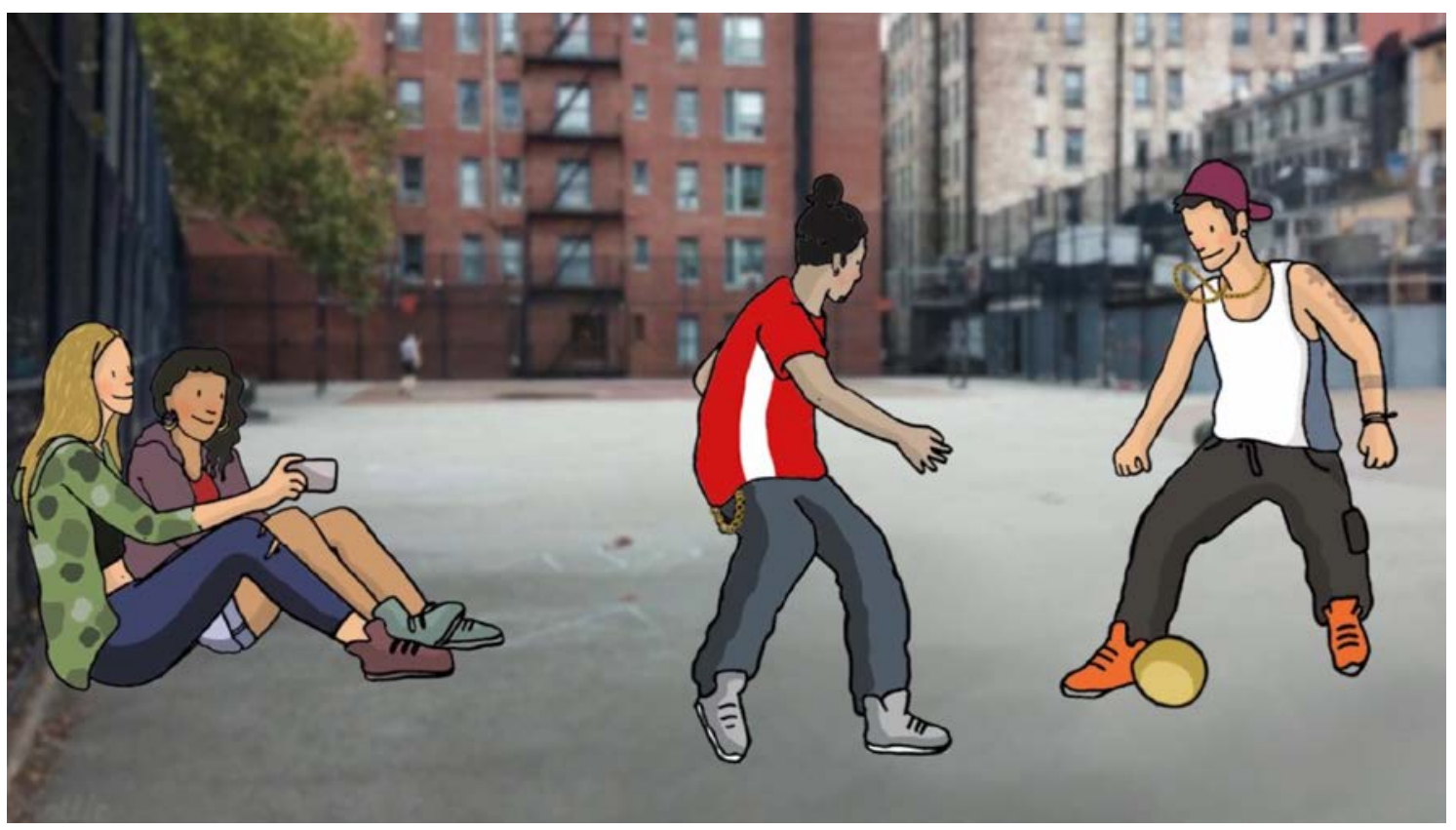

upf. $\begin{aligned} & \text { Universitat } \\ & \text { Pompeu Fabra } \\ & \text { Barcelona }\end{aligned}$
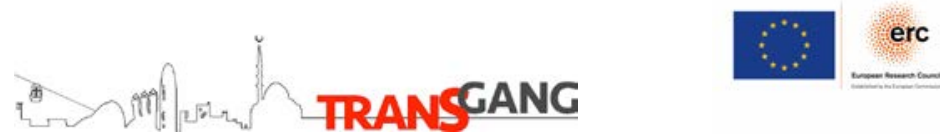
TRANSGANG. Legal Considerations concerning Youth Street Groups in TRANSGANG regions TRANSGANG Working Papers

Number: 3.1

SN: TRANSGANG_WP03.1/2019

Edition: July 31, 2019

\section{Authors}

José Sánchez-García (Scientific Coordinator), Andrés García-Berrio (Legal Advisor), Adam Brisley, Maria-Jose Masanet (UPF Researchers), Paolo Grassi, Juan Camilo Mansilla, Fulvia Márquez, Ligia Lavielle, Candy Chévez, Rachid Touhtouh, Sihem Najjar, Beladaci Larbi (Local Researchers), Carles Feixa (Principal Invetigator),

Work distributed under CC licence

\section{c)}

\section{(C) TRANSGANG \& UPF}

\section{Recommended format for citation}

Sánchez-García, J. (Coord.), García-Berrio, A., Brisley, A., Masanet, M.-J., Grassi, P., Camilo Mansilla, J., Márquez, F., Lavielle, L., Chévez, C., Touhtouh, R., Najjar, S., Larbi, B., \& Feixa, C. (Dir.). (2019). Legal Considerations concerning Youth Street Groups in TRANSGANG regions (TRANSGANG Working Papers 3.1). Barcelona: Universitat Pompeu Fabra \& European Research Council. DOI: http://dx.doi.org/10.31009/transgang.2019.wp03.1

ISBN: 978-84-09-13721-3.

www.upf.edu/web/transgang

transgang@upf.edu

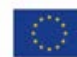

The TRANSGANG project has received funding from the European Research Council (ERC) under the European Union's HORIZON 2020 research and innovation programme under grant agreement $\mathrm{n}^{\circ} 742705$ 


\section{Table of Contents}

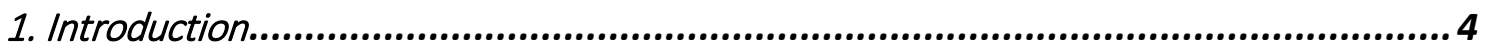

2. General perspective on gangs and law ............................................................ 6

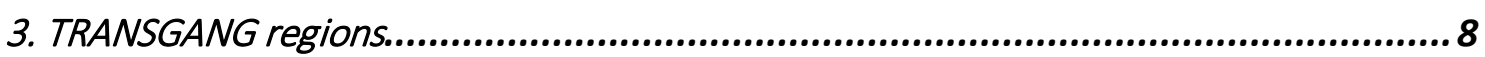

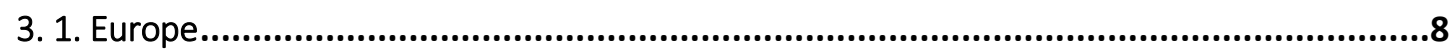

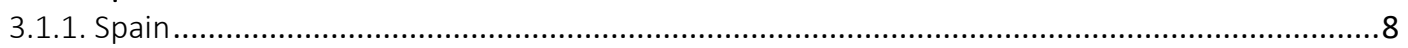

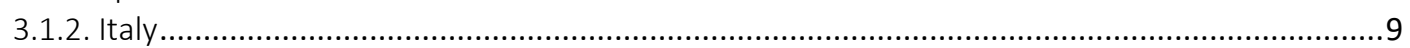

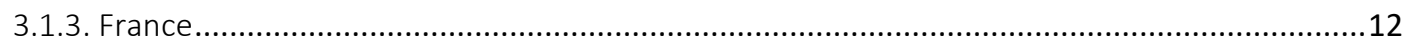

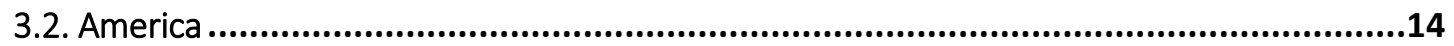

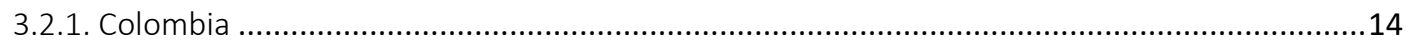

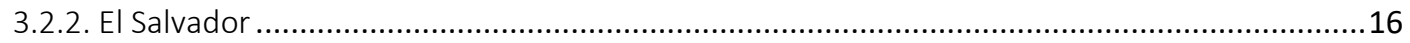

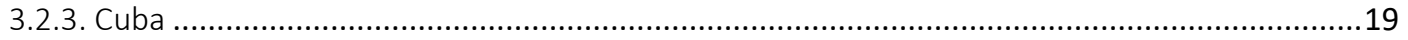

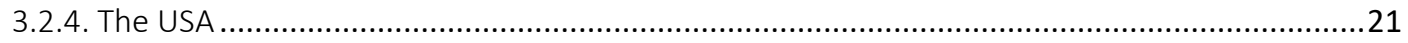

3.3. North Africa .....................................................................................22

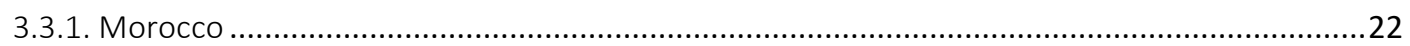

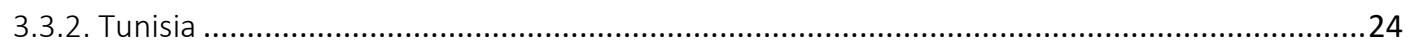

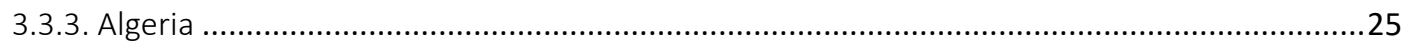

4. Recommendations for fieldworkers...................................................................28

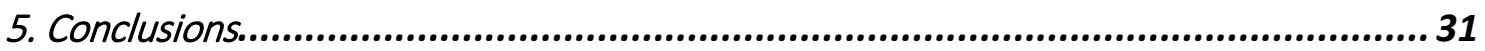

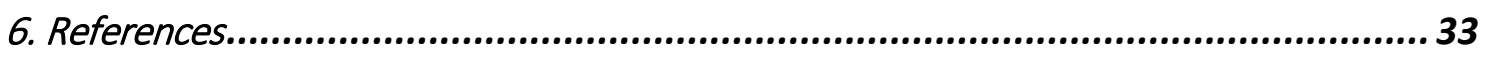

Table of Illustrations

Table 1. Example of risks and actions. 


\section{Introduction}

This document presents the final requirement of the ERCEA panel of experts concerning the "disclosure policy relating to evidence of risk of harm to individuals or groups". After four rounds of questions by the experts, the document was finally approved with the requirement of delivering another document explaining the legal context in each country participating in the project: "Legal Report on Disclosure Policy" (Deliverable 1.3). These questions and answers were sent to ERCEA between the selection of the ERC Advanced Grant (April 2017) and the signing of the Grant Agreement (December 2017).

The objective of this document is to respond to the ERCEA requirement to ensure that all the researchers and institutions engaged in the project have the necessary knowledge on legal rules and the help of legal advisors to guarantee that the project fulfils the legal requirements in each country. Moreover, the document is a guideline for ensuring that all the recruitment process procedures described in Deliverable 1.1 (final version sent to ERCEA in November 2017) and the approved consent forms included in Deliverable 1.2 (final version sent to ERCEA in February 2019) are adapted to the political, legal and institutional circumstances of each location according to the particular country's legal requirements.

When all the question rounds were finished (September, 2017), the expert panel remarked that "because limits to confidentiality can be imposed by legal obligations on researchers to disclose certain information to local or national authorities, the incidental findings policy needs to be based on an analysis of the legal situation. If no such legal obligations apply then the plans to refer incidental findings to the project Ethics Board may be adequate, but this needs to be confirmed by the applicant”. Accordingly, the P.I. requested the lawyer Andrés García Berrio to make the basis for this legal report in November 2018. In parallel, the project's local researchers were asked to analyse the legal norms in their countries, and their results are included in this report. The first documents were collected in April 2019 and, after a review, a second round of country reports was compiled in June 2019 to prepare this final edition. In addition, these analyses will be part of the Background Papers written by TRANSGANG local researchers.

The text is organized in five sections. Section 1, prepared by Carles Feixa and José Sánchez-Garcia, is this introduction to the entire document. Section 2, prepared by Andrés García Berrio, gives a general overview of youth street groups in legislative codes. Section 3 contains analyses of the legal codes for each TRANSGANG country. The section on European laws was prepared by our legal advisor, Andrés García Berrio, and the local researchers: the Spanish subsection was prepared by Andrés García Berrio; the Italian legal codes were prepared by Paolo Grassi (Milano local researcher); the French analyses are by Juan Camilo Mansilla (Marseille local researcher). The section on American laws was prepared by local researchers: Fulvia Márquez for Colombia, Ligia Lavielle for Cuba with the help of the legal advisors of the Orient University in Santiago de Cuba, and Candy Chévez for El Salvador. As an exception, the section on the laws in the USA was written by Andrés García Berrio because a local researcher has not yet been 
selected for Chicago. The section of North African countries was produced by local researchers: Rachid Touhtouh for Morocco, Sihem Najjar for Tunisia and Beladaci Larbi as Algerian TRANSGANG legal advisor. Section 4 contains a list of recommendations for fieldworkers, extracted from the previous sections, and prepared by Adam Brisley, Ethical Transgang Supervisor. Section 5 is the conclusive comparative reflection, prepared by Andrés García Berrio as the TRANSGANG Spanish Legal Advisor. The entire document has been compiled by the Scientific Coordinator, José Sánchez-García, revised by the PI Carles Feixa, and edited by the Project Manager, Maria-Jose Masanet. 


\section{General perspective on gangs and law}

Understanding the legal reality of youth gangs is not a simple task. Throughout history most studies on the subject have been based on the North American model, which has a predominately criminal focus. From this perspective, it punishes and penalizes this type of group in the different countries based on a social and collective imagination constructed from the stigmatization generated largely by the mass media and by immigration and integration policies of doubtful morality.

In US criminology, the term "gang" is a phenomenon that generates large controversies and its translation to other languages is not optimal. The EUROGANG Network ${ }^{1}$ (1988), whose objective is to develop methodological instruments for studying youth gangs and establish comparisons between Europe and the United States, formulated the following common definition for the term youth gang: "a durable youth group with an orientation towards the street and other public spaces and with a group identity defined primordially by participation in criminal activities". Including "criminal activities" as an intrinsic component of the definition of youth group contributes to reinforcing negative stereotypes of marginalized young people who belong to ethnic minorities or immigrant groups. From this critical perspective it can also be seen that it is very difficult, if not impossible, for the operators of the criminal justice system and social services to determine when a certain group of young people, some of whom probably perform criminal acts, is a gang or not. It is also difficult to establish whether a certain individual is simply a friend of gang members or a "member" of the gang. However, it would be wrong to think that all gang members participate in criminal behaviours. The use of this evidence naturally makes us doubt the objectivity of the examination of the relationship between young people and gangs. For example, many young immigrants live in districts where there are street gangs, they have the same clothing style or have purely friendly relationships with gang members without being members of a gang. Moreover, the social alarm that is generated by media attention to Latino youth groups, is an internal concern for the justice system, which takes measures that do not always favour the mediation of the conflict, applying hard-line policies and zero tolerance.

Although criminal acts should not go unpunished, the collective penalization processes towards certain ethnic, cultural or racial groups is part of the racist and discriminatory system in which we live and which violates certain fundamental human rights. A person cannot be penalized for having a certain nationality, or be considered a gang member for this reason. Neither can it be assumed that because a person belongs to a gang they commit criminal acts (in many countries there is a presumption of guilt, contrary to the so-called presumption of innocence regulated in the Spanish penal code). It also needs to be highlighted that the professionals in charge of security and justice do not have sufficient training in this issue.

\footnotetext{
${ }^{1}$ https://www.umsl.edu/ccj/Eurogang/euroganghome.html
} 
It is essential that the situation be addressed from a prevention viewpoint, focusing the intervention on preventing that young members of youth groups enter criminal situations. For this, social intervention is essential from a intersectional and complex view and sufficient economic resources need to be allocated for the social problem. The combination of racism and social exclusion can generate processes in which the people who form part of youth gangs may be forced to commit a crime, or at least, they will be more motivated to do crimes the greater the situation of social exclusion. Having looked at the legal situation in general, the report will now analyse the different current legislations in the countries where data will be collected for the project. 


\section{TRANSGANG regions}

\section{1. Europe}

Europe is one of the continents that most stigmatizes the youth gangs of extra-community origin, as these are defined with exclusively criminal connotations. It is interesting that groups of young people of Latin American or Arab (and others) origin, are labelled "street gangs" and other offensive terms based entirely on their ethnic origin, and the social alarm that this causes. That socially "alarming" behaviour can be seen in a different way, even in the terms of the law, for reasons of race and ethnic origin is a component of racist discrimination that translates into various forms in all of the legal codes that we are going to analyse (Kazyrytski, 2017, p. 302).

\subsubsection{Spain}

In Spain, the influx of migrants of Latin American origin in the first decade of the 21st century led to an increase in the presence of young Latinos in the streets. This generated hostile discourses that rejected the new youth culture of the young migrants. In this context, the term "Latino Gang" was increasingly being used with negative implications. The excessive alarmism about the presence of Latin American gangs in Spain contributed to promoting changes in criminal law.

Since the last decade, the Fiscal Ministry considers youth gangs, especially of Latin American origin, a truly worrying element and factor of criminality (Canelles, Scandroglio \& Lahosa, 2012). The Spanish police authorities and other security forces have officially recognized them as criminal organizations (Kazyrytski, 2016, p. 2). Since then, and taking into account the crucial role the media play in configuring public opinion and collective fear, the processing of Latino street gangs has become far stricter (Kazyrytski, 2017, p. 301). The hardening of legal regulations after the reform of the Penal Code of 2010, which includes gangs in the "criminal association" category, the new police behaviour models and the increasingly active role of prosecutors have all contributed to greater punitive pressure on gangs. These measures emphasize the need to deport gang members to their respective countries.

The entry into force of Organic Law 8/20067, which modifies Organic Law 5/2000 that regulates the criminal responsibility of minors, signifies a hardening in the measures that can be imposed on young people if at the time of committing an offense they belong to a gang. Currently, according to Art. 10.b, if a minor has committed a crime and they are a member of a gang, their time at juvenile facilities can become six years compared to the maximum of two years as a general rule established in the law.

Although police data and criminological studies carried out in this field show that the nature and organization of Latin American gangs do not justify describing them as highly dangerous or criminal organizations, in Spain, there has been a hardening of the criminal policy with respect to Latin American gangs. The processing of these groups has become 
very difficult: laws have become harder and the repressive nature of the entire system of law enforcement has intensified. Therefore, it can be supposed that the phenomenon of Latino street gangs and their negative connotations is a social construction rather than a reality. The stereotypes of gang members are so deeply rooted that many institutions refuse to cooperate with young Latinos in the belief that they are gang, which leads to arrest and processing (Kazyrytski, 2017, p. 313).

From the point of view of the Spanish police, Latino street gangs are organized crime groups, which legitimizes the imposition of stronger sanctions against them (Rodríguez Díaz, 2016). The repressive treatment of street gangs by the police has increased as a consequence of the large direct pressure from prosecutors and the judicial system. Notably, under the National Service Circular of Persecution 2/2011, Latino gangs are covered by Organic Law 5/2010 because they are considered highly dangerous and their criminal orientation turns them into a form of organized crime (FGE, 2011). Under this document, any street gang composed of young people of Latin American origin and which has a name for identification will be considered organized crime by default.

In 2005, the Barcelona City Council promoted and led a study (the JOVLAT project) that included interviews with young Latin Americans belonging to the Latin Kings and Netas gangs. This initiative led to a truce between these two groups, who participated in some meetings. From there, a dialogue was initiated with the intervention of the Public Ombudsman, the City Council of Barcelona and the local police force (Mossos), which led to the legalization of these gangs and their constitution as youth associations. In this context, they carried out diverse cultural and participative activities and there was a real decrease in conflicts ${ }^{2}$. In fact, "Only $1 \%$ of crime in Spain can be link to these groups, but in prisons the percentage of inmates who belong to gangs is much higher".

\subsubsection{Italy}

According to the TRANSGANG project, the existence of a gang implies the presence of five indicators: a) a name; b) an external label; c) an internal awareness; d) ordinary activities; and e) continuity over time. If we consider this definition, with regard to the Milanese case study, we have to focus our analysis mainly on Latin American gangs. At a legal level, Latin American gangs in Milan first appeared at the beginning of the 2000s. In fact, according to the social researcher Tommaso Comunale ${ }^{3}, \mathrm{PhD}$ candidate at the Catholic University of Milan, the first police operation dates back to 2005 and was called "Street Fighter". The main gangs involved were the Latin Kings and Commando, mostly formed by young Ecuadorian and Peruvian citizens. Then, between 2012 and 2015 four police operations cut the heads off all the Latin American street groups. The first operation (the "Mareros" operation) was in 2012, and was against young Salvadorian members of Mara Salvatrucha; the second operation (“Amor de Rey”) was in 2013,

\footnotetext{
${ }^{2}$ https://www.upf.edu/es/web/comunicacio/noticies//asset_publisher/Z43gkEdp7zFm/content/id/216319641/maximized\#.XRODQJMzbBJ

311 January 2019.
} 
against Ecuadorian and Peruvian members of the Latin Kings (Chicago and Luzbel), Trebol and Netas; the third operation ("Trinitario") was in 2013, against Dominican members of Trinitarios; the last operation was in 2015 ("Barrio 18”), mostly against young Salvadorian members of Barrio 18. The five operations investigated around 200 people for criminal association, attempted murder, grand larceny, drug trafficking, illegal possession of weapons, extortion, and rape. The biggest operation was “Amor de Rey", which investigated around 75 people. Gangs in Italy can be associated with criminal associations ("Associazione a delinquere" in Italian), regulated by article number 416 of the Italian penal code:

Quando tre o più persone si associano allo scopo di commettere più delitti, coloro che promuovono o costituiscono od organizzano l'associazione sono puniti, per ciò solo, con la reclusione da tre a sette anni. Per il solo fatto di partecipare all'associazione, la pena è della reclusione da uno a cinque anni. I capi soggiacciono alla stessa pena stabilita per i promotori. Se gli associati scorrono in armi le campagne o le pubbliche vie, si applica la reclusione da cinque a quindici anni. La pena è aumentata se il numero degli associati è di dieci o più 4 .

An academic article written by the jurist Joseph Moyersoen in 2016 analyses the reconstruction of the first criminal sentence of the "Giudice dell'udienza preliminare" (Preliminary hearing judge) of the juvenile court of Milan in $2010^{5}$. This was the first sentence of the juvenile court of Milan against Latin American gangs (Latin Kings and Commando). On that occasion, the judge also alleged the crime of criminal association. (Moyersoen 2016: 136).

Latin American gangs in Milan are a marginal phenomenon that currently involves a small number of young people. A policeman and member of the flying squad of Milan confirmed this during an interview on 29 April 2019. He explained to me how they started to investigate on these groups:

We have been dealing with gangs since they appeared as a phenomenon. It was at the beginning of
2000s when people began to understand that behind some assaults, some violent acts, there was a more
general framework, a fight among gangs that initially was not understood. Several people came to us to
denounce or request our intervention [...]. So then we tried to understand and investigate the
phenomenon [... ] We had to investigate in a wider context, not only behind the single aggression, the
single violent act, but within a broader framework. And then we understood, obviously also with the
help of the technical activity of the Judicial Police, that these people were organized in real associations.

There are various reasons why Italian law enforcement seemed to succeed in controlling this phenomenon. During an interview, the researcher Tommaso Comunale highlighted some of them, also referring to his conversations with an ex-gang member: "This member

\footnotetext{
${ }^{4}$ When three or more subjects join in order to commit crimes, those who promote or constitute or organize the association are punished, for that reason alone, with imprisonment for three to seven years. For the sole reason of participating in the association, the penalty is imprisonment for one to five years. The leaders are subject to the same penalty established for the promoters. If the members run countryside or public streets with weapons, they will be imprisoned for five to fifteen years. The penalty is increased if there are ten or more associates (Translated by the author).

${ }^{5}$ Sentence number 403, 4th of May 2010.
} 
said to me that there are three main differences [between Italy and Central America]: a penal system that works; the Italian state is less corrupted; and, finally, the police control the territory efficiently".

With regard to the first point, in Milan there are three prisons: "Carcere di Bollate", "Casa circondariale Francesco Di Cataldo - Milano San Vittore”, and "Casa di Reclusione di Milano Opera". There is also a specific institution for mothers, "ICAM - Istituto a custodia attenuata per detenute madri", and a juvenile prison, the "Centro per la giustizia Minorile Cesare Beccaria”. Conditions change a lot depending on the institution. The first one - Bollate - has 1279 inmates. At least 200 of them are women (Ministero della Giustizia, 23 May 2019). Since its foundation Bollate prison has carried out experimental reintegration projects. All sections are open and inmates can leave their cells during daylight hours to participate in work, training or socializing activities (Antigone 2015). The second one - San Vittore - has 941 male and 92 women inmates (Ministero della Giustizia, 24 May 2019). San Vittore is overcrowded and the percentage of foreigners is very high (around 60\%). There are few reintegration projects, which is also because prisoners spend just 2-3 months there on average (Antigone 2018). The third one - Opera - has 1304 male prisoners (Ministero della Giustizia, 24 May 2019). This prison is also overcrowded. Moreover, it has recently been shown to have weaknesses related to health care (Antigone 2018). The juvenile prison of Milan - Beccaria - had 31 male prisoners mainly from Morocco, El Salvador, and Ecuador, on 15 December 2017 (Antigone 2017). On 15 March 2019 I spoke with Don Gino Rigoldi, a catholic priest who has been working at Beccaria since the 1970s. I asked him about juvenile gangs in Milan and the role of penal institutions in rehabilitating their members. Don Gino Rigoldi also explained to me how things can be very different depending on the prison:

[Interviewer] Can prisons be "useful" for these boys? [Rigoldi Answer] As usual it depends on the prison. If you go to [the prison of] Monza and you spend 22 years there, you stay in your cell $[\ldots]$. This doesn't work, you know. The prison can be useful to stop their [the gang members'] "power trip", but you need to create relations [...]. Usually they don't trust anybody. If trusting is seen as something dangerous, the city dies, the city as a complex social system dies. You can create good and deep relations with these boys. They are not "consumers" of relations.

Statistics on incarcerations do not say anything about gangs. There are data on typologies of crime (Tagliafierro, 2015), but in Italy criminal associations also include Mafia organizations; therefore, these numbers are not reliable for the Transgang project. However, an ex-gang member of a Salvadorian clique of Mara Salvatrucha who was imprisoned in Italy for aggravated assault described - during an interview on 8 April 2019 - interesting "gang dynamics” in a Milanese prison:

[In 2013] I went to San Vittore. I lived a life there ... I could never qualify there, because I could never live in a sector. They took me to ray 5, the Latin Kings and the 18 were there. Then I ... I fought one, they even did the "rapporto" to me, pa, pa. They sent me to ray 6 , the MS was there. I couldn't be there, either. So what did they do? They isolated me. I lived almost one year completely isolated in San Vittore, in isolation. I practically had no contact with the other inmates like any common criminal has. They said to me: "Aria", and they 
took me out, all by myself. It was better not to go out, better to be closed in.

This is the only narrative that I have been able to collect as yet on incarcerated (former) gang members, a narrative that seems to show how Latin American gangs were reproducing, at least until six years ago, conflictive relationships in one Milan prison.

In conclusion, in the last fifteen years five police operations have weakened some of the main Milanese Latin American street groups. Nowadays in contrast to other contexts, juvenile gangs in Milan seem to be a marginal phenomenon occasionally associated by the Italian legal system with criminal associations. The Milanese penal system "works", but this depends on the prison. In other words, some prisons are better than others in offering reinsertion programs and alternative measures. At least on some occasions gang members have reproduced conflictive dynamics in the Milanese prisons. In this respect, this will be confirmed or disconfirmed by the development of the upcoming qualitative research.

\subsubsection{France}

This analysis presents a brief history of the evolution of the legal framework of youth street groups in France according to the social and political national context and legal codes concerning Youth Street Groups in France.

The fight against organized crime in France, in its recent history, dates back to 2004. The then president Jacques Chirac, of the right-wing RPR party, and his Minister for National Security and Minister of the Interior, Nicolas Sarkozy, promulgated law n $2004-204$ of 9 March, 2004, "concerning the adaptation of justice to the evolutions of criminality". This law substantially amends the French penal code and, consequently, the judicial treatment of youth gangs. This reform introduces the concepts of delinquency and organized crime into French criminal law, creates the aggravating circumstance of commission in an organized gang, and extends the list of criminal offences that fall within this field. Another major change in this law was the launching, for France, of the European judicial cooperation strategy (EuroJust), a central tool in the fight against transnational criminal gangs. It is important to understand the adoption of this law within the historical context at that time. In the early 2000s, drug trafficking, migrant smuggling, trafficking in human beings, fraud, and of course the money laundering resulting from these crimes, generated new forms of organized crime based on complex networks of transnational operations.

In 2010, Nicolas Sarkozy, this time as president, promulgated law $\mathrm{n}^{\circ} 2010-201$ of 2 March, 2010, "which reinforces the fight against group violence and the protection of people in charge of a public service mission". The aim of the law is to control the youth criminal gangs in the country's lower-class neighbourhoods (the banlieues). In its chapter 1, entitled "Provisions to Strengthen the Fight Against Violent Gangs", the law introduces the offence of preparations for the commission of violent acts in groups, either against people or property. Included in Article 222-14-2 of the penal code, this offence represents 
today the main legal tool of the French state for suppressing the emergence of all kinds of collective dynamics not authorized by the government, whether they are social movements, youth gangs or criminal gangs. The historical context of adopting this law is closely linked to the so-called révolte des banlieues ${ }^{6}$ in 2005.

About legislation, there are several offences in the French legal system that could be applied to the phenomenon of youth street groups. With these measures, the legislator seeks to punish criminal behaviour in which two or more subjects cooperate, in one way or another, in order to infringe protected legal rights. In France, such collective criminal action is an aggravating factor for the legal consequences of the punishable act. This offence is known as "commission in a collective-way" or "complicity” (Article 121-7, Penal Code). Sanctions against individuals belonging to identifiable criminal gangs, or acting in more or less organized ephemeral groups, are increased due to the fact of “committing offences in a collective-way" (Article 375-2, Code of Penal Procedure). The aggravating circumstance of complicity generally imposes imprisonment of at least five years in all the offences. This has an important consequence for the prosecution of members of youth street groups, since they are excluded from a possible alternative judicial treatment". The figure of "criminal composition" (Article 41-2, Code of Penal Procedure), the alternative judicial treatment in France, is applicable to any offence under certain conditions if the penalty contemplated is not five years or more, which thus excludes any offence committed in a "collective-way". The only exception is drawings, or graffiti, committed in a collective-way without prior authorization, on urban real estate and vehicles, which is liable to a fine of 15000 EUR and to community service.

The French legal system has several tools for prosecuting different forms of gangs. If it is a gang structured by an underground economy, then it falls under the provisions related to organized gangs (Article 132-71, Penal Code). If it is about a phenomenon of violence, which is less-structured, there are rules that specifically protect the forces of law and order, in specific situations, such as rebellion and ambush (Article 433-6 and following, 222-15-1 and 132-71-1, Penal Code). In the case of violence between rival gangs, the provisions repressing violence in a collective-way are applied (Articles 222-8, 222-10, 222-12, 222-13, Penal Code), including those relating to offences against property committed in a collective-way (Article 322-3-1, Penal Code). Preventively, those relating to spontaneous gatherings, whether armed or not (Articles 431-3 and following, Penal Code) are also sanctioned. Furthermore, the legal system establishes the offences of occupation, in a collective-way, of buildings' lobbies (Article L. 126-3, The Building Code).

\footnotetext{
6 In October 2005, during a police chase, two young people from Clichy-sous-Bois, a lower-class neighborhood on the northern outskirts of Paris, entered a high-voltage power station and died electrocuted. This generated three weeks of violent confrontations between the police and young people of lower-class neighborhoods, in several regions of the country.

${ }^{7}$ A measure delivered by a judge consisting of an activity of general interest, educational training and/or a fine, in exchange for the ordinary prison term.
} 


\subsection{America}

In Latin America, youth gangs are groups that tend, perhaps unfairly, to be a large part of the security problems of Latin American countries. In Latin America a gang is a street group organized in neighbourhoods with precise geographical limits. Nations represent a higher level of gang organization, with many hundreds of members. Although they may have some criminal connections, the main function of both groups is sociability. They create a distinctive lifestyle that resolves conflict through music and dance challenges, for example. An extreme version of this network, related to Central America in the postwar period, are the 'maras' (Feixa, 1998; Perea, 2007; Reguillo, 2008; Ramos et al., 2013). However, these youth associations have diverse legal situations.

\subsubsection{Colombia}

Colombia has signed several international instruments, while it has adopted and generated its own internal regulations to construct a specialized and differential system for children, adolescents and young people in accord with the Child Welfare Observatory. It also ensures restorative justice that gives guarantees to victims of the crime by repairing the damage.

Various documents stand out in the Colombian legislation related to youth groups, with attention to children, adolescents and young people: The document Conpes 3629 of 2011, issued by the National Council of Economic and Social Policy of the National Department of Planning defining the Adolescent Criminal Responsibility System; Law 1098 of Children and Adolescents of 2006; the Statute of Youth Citizenship; Law 2216 of 2013 and a report of the Child Welfare Observatory. These documents are a tour of International and National regulations that provide the fundamental foundations for legislation on children, adolescents and young people in the country. Therefore, it is important to give a summary of these normative frameworks since they give rise to approaches, principles, and criteria for action ${ }^{8}$.

The protection and care of minors in conflict with the criminal law must take into account the following regulations: (i) the Political Constitution of Colombia, (ii) The Beijing Rules or United Nations Standard Minimum Rules for the Administration of Juvenile Justice, (iii) the United Nations Rules for the Protection of Juveniles Deprived of their Liberty, (iv) the Convention on Children's Rights, (v) the International Pact on Civil and Political Rights, and (vi) the American Convention on Human Rights (Constitutional Court, 2005).

Regarding national regulations, the regulatory framework for the treatment of adolescents and young offenders of criminal law has been developed mainly in accordance with the

\footnotetext{
8 The Colombian Constitutional Court in decision/sentence C-203 of 2005 establishes that the treatment of the justice system for adolescents is regulated both in national norms as well as, and to a large extent, in international norms (Constitutional Court, 2005).
} 
perspective of comprehensive care of children and adolescents. In the centre is the National Constitution surrounded by the constitutional developments reflected in laws, policies and the regulatory decrees of these. However, when we discuss the purposes of this legal note, we will refer only to those regulations directly related to youth street groups.

Thus, Statutory Law 1622 of 2019: Statute of Juvenile Citizenship (2013) defines a young person as, "Any person between 14 and 28 years of age in the process of consolidating their intellectual, physical, moral, economic, social and cultural autonomy that is part of a political community and in that sense exercises their citizenship" (Article 5). The Statute of Youth Citizenship proposes actions and strategies to guide the activity of the State and civil society, in addition to generating the conditions so that young people can exercise their citizenship and their individual and collective life projects in an autonomous, responsible and transcendent way. Finally, it is necessary to highlight that all these measures and legal norms are based on Law 1453 of 2011, or the Citizen Security Law, which introduced changes to the Law on Children and Adolescents and the Penal Code and the Penal Procedure Code. It represents progress in terms of child protection in these, stating, for example, that "in cases where the adolescent has been a victim of the crime of constriction of minors for the commission of crimes or illicit recruitment, deprivation of liberty shall not apply" (Article 90, amendment of 177 of Law 1098 of 2006).

In second place, we find the Criminal Responsibility System for Adolescents (SRPA). The SRPA is aimed at investigating and judging the transgression with the support of specialized rules, procedures and authorities, and under the criterion of specialty and differentiation with respect to adults. In this sense, and consistent with what is defined by the Code of Childhood and Adolescence, the SRPA defines that "An adolescent offender of the criminal law is one whose responsibility has been determined as author or participant, either by act or omission, intentionally or guilty, of a punishable conduct typified in the Code of Childhood and Adolescence as a crime or contravention”. In Colombia, adolescents who commit crimes are subject to the doctrine of comprehensive protection, which involves moving from a conception of minors as objects of guardianship and segregated protection, to be considered as full subjects of the law. Therefore, the orientations and actions of the SRPA "are structured around the concept of integral protection to the minor that is guided by the principles of interest, right, coresponsibility, enforceability of rights, gender perspective, multiculturalism and parental responsibility" (Supreme Court of Justice, Process N 35681, M.P. Julio Enrique Socha Salamanca, 29/06/201 (Quoted by Torres, 2011, p. 123).

In summary, the national and even local normative frameworks highlight that constitutionally the superior and prevailing nature of the rights and interests of children, adolescents and young people has been recognized, which should guide the normative diversity that the issue of criminal justice is available for this age group. All the rules and judgments reviewed show the co-responsibility of the State, the family and society in general, both for the guarantee of rights, as well as for the treatment and process of resocialization and reintegration of children and adolescents and young people who are in 
conflict with the Criminal Law (Observatory of Child Welfare 2015).

Finally, despite the laws issued focussed on rights, human development and human dignity, based on the concept of restorative justice, the Colombian State continues to give the leading role to the criminal justice system. Thus, it limits the possibilities that other facilitators or mediators (such as the community, social professionals, interdisciplinary teams, etc.) could manage mediation processes and help build coexistence and justice (Child Welfare Observatory, page 16).

\subsubsection{El Salvador}

In 1992 El Salvador signed the peace treaty of a 12-year armed conflict between the national army and the Frente Farabundo Martí. The 1990s represented for the country the end of the war, the implementation of neoliberal economic policies and the emergence of a new social context of violence that was born out of a peace process that did not take into consideration the reintegration of the armed forces into civil life with dignified conditions; the return of thousands of Salvadorans who had migrated to the US due to the armed conflict (many of them linked to the gang culture in the US) and who returned without a State social program that would allow their incorporation; as well as the limited programs for young people of the so-called "student gangs" that existed at that time. This context became the stage for the emergence of a new social actor in the violence, the "maras or gangs". Large numbers of young people who began to organize themselves around cultural practices similar to those of the gangs in the US, as a form of internal functioning, and criminal practices, as a way of obtaining their economic resources.

\section{History and evolution of the law against criminal groups}

Although the presence of maras or gangs in Salvadoran neighbourhoods is recorded before the end of the war and in the nineties there was already, in Salvadoran public opinion, cause for social unrest, it was not until July 2003 that the Government of Francisco Flores identified the gangs as a problem of the first order and declared them to be a threat to national security. With the implementation of the Mano Dura Plan (20032004) and the Super Mano Dura Plan (2004-2006), joint police and military patrols, sweeps of marginal communities and mass arrests of alleged gang members based on their physical appearance increased. These mass arrests, abuse of authority and violations of human rights generated a counterproductive effect of increasing rates of violence: homicides increased significantly (the rate per 100 thousand inhabitants went from 37 per 100 thousand inhabitants in 2003 to 65 in 2006) and from inside prisons the gangs strengthened both their structures and their criminal involvement.

A second impact of this policy was the construction of the social imaginary of the "maras or gangs". All the police actions were accompanied by extensive media coverage that presented the gang members only as criminals, separated from structural factors, and which argued that hard-line policies were the only possible response to such a problem. In effect, the strategy gave the government the image of being hard against crime, which 
was widely recognized as positive by the population tired of chronic insecurity. This period was characterized by abuses of authority and lack of a comprehensive policy. Both the Mano Dura and the Super Mano Dura were plans designed as part of the same political strategy, which essentially appealed to the deployment of the police and military force for the persecution and selective capture of anyone who was presumed to be a member of a mara or gang. However, throughout its implementation, variations were incorporated in the components of the plans, especially during the Antonio Saca administration (20042009), which formally introduced prevention and rehabilitation programs together with the repressive component. Although in practice, these "soft hand" components had a residual weight in the security policy, it was a governmental recognition of the need to address the gang phenomenon with comprehensive approaches.

In 2009, and after two decades of right-wing governments, a leftist government came to power, and with it the possibility of reforming the security issue. Upon its arrival, the new government recognized the need for a comprehensive approach for dealing with crime, including that associated with gangs, as well as the urgency of in-depth reforms to professionalize security institutions. The proposal to comprehensively address the criminal phenomenon that had constituted an important campaign promise, led to the formulation of a security policy document with a strategic approach and comprehensive intervention, which would later become the Policy of Justice, Security and Citizen Coexistence proposal. The policy formally adopted by the Ministry of Justice and Security called "National Policy of Justice, Security and Coexistence" that had been formulated in the first months of the new government with the contributions of different social and political sectors, was not implemented by the new Government. The policy remained in a good document that was not implemented and with which El Salvador lost one of its main opportunities to respond to this problem. On the contrary, the leftist government increased the participation of the military in public security and more repressive measures were generated. In 2012, an attempt was made by the government to negotiate with gangs, which was not well seen by society or opposition parties. This led the government to deny this process and incriminate the people who had acted as "negotiators". In 2014, with the arrival of the second left government, a public declaration of war against the gangs was made, denying any possibility of dialogue and/or negotiation. This position strengthened military, repressive and punitive measures to address this problem. Finally, 2019 represents an uncertain period in terms of the State's security policies. On 1 June of this year, a new government of the GANA (centre-right) party started its administration. Although it is not clear what will be their security policy, this party has historically shown an extremely repressive and punitive attitude towards the issue.

\section{Legal framework}

Currently, the laws that are in force to address the "maras or gangs" in El Salvador are:

a. Law prohibiting maras, gangs, groups, associations, and organizations of a criminal nature. Decree No. 458 approved in 2011. 
Art. 1.- The so-called maras and gangs are illegal and are banned, such as the self-named Mara Salvatrucha, MS-trece, Pandilla Dieciocho, Mara Máquina, Mara Mao Mao and criminal groups, associations or organizations such as the self-named Sombra Negra; therefore, the existence, legalization, financing and support of these is prohibited. This prohibition applies to the different maras or gangs, and criminal groups, associations, or organizations, regardless of the denomination they adopt or even if they do not assume any identity."

"Art.- Girls, boys and adolescents who are identified as members of maras, gangs, or criminal associations or organizations, who, due to their age cannot be criminally prosecuted, or due to their situation of serious risk, will proceed with what is established in the laws of the matter and the Attorney General of the Republic will be notified, so that the protection processes may take place.

b. Special Law against acts of terrorism, approved in 2016, which has as its main objective:

Art. The purpose of this Law is to prevent, investigate, punish and eradicate the crimes described therein, as well as all their manifestations, including their financing and related activities, and that by the manner of execution, means and methods employed, evidencing the intention to cause alarm, fear or terror in the population, by imminently endangering or affecting the life or physical or mental integrity of people, material goods of significant consideration or importance, the democratic system or the State security or international peace; all of the above, with strict adherence to the respect for Human Rights.

This law places the "maras and gangs" in the category of "terrorists"; thus, worsening their image at the same time that the laws, punitive actions and repression by the police and military forces became harder. The law defines terrorist organizations as:

Those groups with a certain structure from which fairly stable or permanent links originate, with hierarchy and discipline and with appropriate means, who seek the use of violent or inhuman methods with the express purpose of instilling terror, insecurity, alarm, assuming the exercise of powers pertaining to the sovereignty of the states or systematically affecting the fundamental rights of the population or part of it, of one or more countries.

In the case of adolescents and young people between the ages of twelve and sixteen who are involved in illicit groups, the juvenile criminal law is applied:

The antisocial behaviour of minors whose ages are between twelve and sixteen years that constitutes a crime or offence shall be established through the procedure regulated in this Law. Once the facts constituting the antisocial conduct have been verified, the Juvenile Judge shall decide to apply to the minor any of the measures established in the Law of the Salvadoran Institute for the Protection of Minors or the measures contemplated in this Law, provided that they are in the best interest of the minor. Minors who have not reached twelve years of age and have antisocial behaviour will not be subject to this special legal regime, nor to the common one; they are exempt from liability and, where appropriate, the Salvadoran Institute for the Protection of Minors must be notified immediately for their full protection.

\section{Approach strategies}

Historically, the approach for the criminal groups called "maras or gangs" in El Salvador has mainly followed two lines: A repressive, military and punitive strategy that has increased the rates of violence and the denunciations of human rights violations by the 
police and military forces, especially towards young people. The second strategy of the government has been through religion, prioritizing the incorporation of churches and their programmes at different levels of intervention. The Safe El Salvador Plan, which was the Government's Security Policy between 2014-2015, prioritized five work areas: prevention of violence, criminal control and prosecution, rehabilitation and reintegration, victim care and protection, and institutional strengthening.

The axis of rehabilitation and reintegration is considered among one of the actions:

Continue the Programme "Metamorphosis", whose main objective is the rehabilitation of the male population in the El Salvador prisons by teaching the Word of God and training them in skill that allow them to become healthy and productive people ready to be reinserted in society.

The policy implemented during this last period has been characterized by these two strategic lines; however, the security policy for the next five years has not yet been defined.

\subsubsection{Cuba}

Any approach to the Cuban penal code on groups that commit crimes in the informal territorial framework of the streets, that which is the action of gangs or organized crime, immediately comes across a vacuum. It must be said that the official discourse of the Cuban state structure does not recognize the existence of such informal collectives, and this is what their information bodies express. This does not mean that there is no social impact of informal groups on public space, but rather the penal code does not refer to the treatment of criminal behaviour in street spaces committed in a group manner.

Informal youth groups are represented in the penal code in the general norms of criminal law. Cuban Criminal Law is the platform for inquiring about the sanctions that fall on members of informal youth groups who manage or participate in criminal actions. For López Soria (2011, p. 4-5) the centre of Criminal Law is the Penal Code in its Law 62, of 1992, in which the infractions that serve as referents are indicated. The author also points out sub-sections of Criminal Law: Law number 93 against terrorist acts of December 2001, the Law on Military Crimes, and Law number 88 of 1999 for the protection of national independence and the Cuban economy, among others.

We will focus our attention on the first of these. This law states clearly that there is no specific space dedicated to contraventions or crimes carried out in a coordinated manner on the streets, or in gangs. Rather, each crime will be treated according to the infraction carried out by each subject of the group. Cuban law places more emphasis on the damage caused to people or the national heritage than to the characteristics of the infringing agents. 
In that sense, we can mention some infractions and crimes $^{9}$ included in the Penal Code and that may be carried out by informal street groups, mainly juveniles:

\section{Article 72 of the Penal Code: The Danger Index}

This is the proclivity or particular tendency that individuals have to commit crimes, which is demonstrated in their public conduct. This includes those who consume drugs, perform public acts of violence or do not engage in any work (state or private) while they are in public space. See below the detailed explanation given by López Soria (2011, p.21). The behaviours that denote being in a State of Danger, are regulated by law and are: a) habitual drunkenness and dipsomania (both seen as personal excesses in the ingestion of alcoholic beverages), b) use of narcotics (another personal excess, but now in relation to the use of drugs), and c) antisocial behaviour (in which the person who usually breaks the rules of social coexistence, through acts of violence, or other provocative acts, violates the rights of others or due to their behaviour in general damages the rules of coexistence or disturbs the order of the community, or lives off the work of others or exploits or practices socially reprehensible vices), this behaviour includes, for example, those who practice prostitution, and those who, although they are physically and mentally able to work, decide not to do so and are sustained at the expense of the work of others.

\section{Title VI of the Penal Code on associations considered illegal}

All associations, manifestations and meetings that attempt against the Cuban political social system (Article 208 and 209) and are not registered in the law, are considered illegal and are punishable. By other side, Title VI on public disorder and attacks against the symbols of the fatherland or foreign national symbols, includes the collective alteration of public order, damaging national symbols, busts of presidents or any other national emblem. Also outside the penal code there are contraventions that concentrate in Decree Law 272 (Riestra, Pañellas, Rodríguez, Torralbas, 2009, p. 7), which deals with infractions in public space. For example, law 18 establishes the care of the lawn. Within this there are regulations for monuments. In addition to what has been said above, attention must be paid to other subplots of Penal Law, beyond the Penal Code and its Law no. 93, since it does not have a particular space to deal with informal groups of public action, it may occur that such agents carry out actions whose penalization corresponds to the other subplots of Cuban Criminal Law.

\section{On penalties}

We will take a brief look at some penalties for the crimes and contraventions stated above. Nevertheless, the penalties are subject to the provincial court, a body that meticulously

\footnotetext{
${ }^{9}$ At this point it is necessary to establish the difference between contravention and crime. Pérez Soria (2011, pp. 12-13) explains that: the contravention contravenes, is contrary, is the infraction or disobedience to a law or order. In our country, they are administrative, they deal with and are punished administratively and not criminally by the bodies empowered to do so. The contravention does not have legal-criminal treatment, nor does it create a criminal record. Crime, on the other hand, does have legal-criminal treatment and creates such antecedents.
} 
analyses mitigating factors, highlighting, for example, age. Among the measures applied to those who are considered in the Danger Index are: internment in a specialized work or study centre; delivery to a work collective for control and orientation of the behaviour of the subject in a Dangerous State. On associations considered illegal, article 209 of the Penal Code sanctions with the privation of liberty for one to three months or a fine of up to 100 pesos those who participate in meetings or demonstrations that are not legally declared. Contraventions receive fines of between 10 and 300 pesos in relation to the seriousness of the infraction.

Campoalegre and Portieles (2013) summarize the contributions of the Cuban penal system for the treatment of criminal acts by children under 16, specifically the opening of a particular space in the Cuban legal body. In this sense, Decree Law number 64/82 judicially differentiates minors and young people. The first are not judged by ordinary courts, but rather by the Child Care Councils. A system is established based on a psychopedagogical conception, established by the Ministries of Education and the Interior. The administrative procedure is adopted for the care of children under 16 years of age who have behavioural disorders, antisocial manifestations, whether or not they become significant indexes of deviation or "social dangerousness", or participate in acts that the law classifies as crimes for adults (Campoalegre and Portieles, 2013, p.6).

\subsubsection{The USA}

The USA has one of the most punitive frameworks against the youth gang phenomenon, as the mere "conspiracy" to commit a crime is punished. Since the 1950s, in this country, gangs have mainly been investigated by the judicial police, who focus primarily on crime, leaving aside other aspects such as, for example, cultural practices.

The street gangs of North America are closely linked to the process of urbanization in the United States, and to the process of "magical recovery" of the original ethnic identity by the second and third generations of young people with a migratory background. This trope of recovery was translated into the model of the territorial gang, well organized and basically composed of men: the classic object of urban ethnography (Thrasher, 1926; Whyte, 1943; Klein, 1995).

If, instead of stereotyping the gangs as violent and criminal groups, they are conceptualized as a particular form of social organization within a community, the debate overcomes the subjective judgment of good and bad and concentrates rather on the gangs, their acts and their repercussions. Gangs are just one of the many social actors in a community and which can have a positive or negative effect on communities, depending on the role they play. In some cases, they act as predators and cause fear and insecurity; in others, they offer a form of protection that the community does not receive from the State's security forces. This does not mean that they are dangerous or benevolent, but rather to understand the phenomenon of gangs, it is necessary to move beyond the mere evaluation of the threat that they pose.

However, in the US, very punitive approaches to the problem have gained strength. The 
term "spaces without government" was coined by George Shultz, former US Secretary. Since then, it has gained prominence in the vocabulary of the armed forces of the United States and in the debates about failed states and wild cities. The concept captures the lack of an effective State presence in certain countries or cities. For the US government, the main concern is that ungoverned spaces can provide refuge for terrorist groups, such as Al Qaeda and other armed groups and gangs, which could take advantage of the lack of government presence in the areas where they operate. The State sees spaces without government as threats because they allow the establishment and expansion of the power of armed groups, the free development of their activities, the alteration of the norms that are used to govern these places and the increase in illicit activities that they usually contribute to the support of armed groups.63. In other words, spaces without government offer armed groups a base to plan, prepare and launch attacks against the State.

\subsection{North Africa}

In Africa, Mediterranean Arab youth subcultures include street vendors, hooligans, rappers, hittistes and tcharmil. In countries such as Tunisia, Algeria and Morocco, this emerges in a process of hybridization with their own cultural traditions of North Africa, marked by the importance of family and morality (Bayat, 2012; Nilan, 2016; Sánchez García, 2011; Camozzi et al., 2016). In any case, the tradition of gangs as a form of youth sociability is alien to their own cultural forms, and therefore, legislations correspond to traditions far removed from North American criminology, although they can be influenced by the colonial processes suffered in the area, for example in Morocco. Thus, to describe the state legislative initiatives that follow, it seems pertinent to understand them, in the North African context, as a mechanism of power to establish governability. In the absence of explicit legislation on the gang phenomenon, except in Morocco, in any of the North African countries participating in the project, legislative discourses to define potentially dangerous behaviours use, in a precise manner, certain concepts with floating meanings that have allowed them to repress the juvenile practices considered as deviant, which include from political dissidence to radical groups of soccer fans passing through sexual orientations that are considered immoral.

\subsubsection{Morocco}

Morocco is a signatory of a number of treaties with privacy implications, such as the Universal Declaration on Human Rights; the International Convention on Civil and Political Rights; and the International Convention on the Protection of the Rights of All Migrant Workers and Members of their Families.

The Moroccan criminal code devotes a whole chapter in the Penal Code to criminal acts as part of a group or "gang". Although the text does not refer explicitly to the notion of 
gang, there is an equivalent Arabic term used to mean gang ${ }^{10}$. Chapter V of the Moroccan penal code entitled "Crimes and Crimes Against Public Security" is devoted to the criminal procedures applied to forming gangs and performing violence in the public sphere. The first section titled "Association of Malefactors and Assistance to Criminals" deals with all the aspects of forming gangs and crimes from articles 293 to articles 333.

The Moroccan penal code defines the forming of a gang in these terms:

Any association or agreement, whatever its duration and the number of its members, formed or established for the purpose of preparing or committing crimes against persons or property, constitutes the crime of criminal conspiracy which exists by the sole resolve to act jointly.

The Moroccan legislator, according to the definition, does not use the term "gang", the term association is used instead, so any grouping of more than one person to commit a crime is a form of gang. Moreover, the legal code does not refer to one gender, so men and women are both considered potential criminals in this case. The formation of a gang is not conditioned by time or space, and even the intention of the criminal act is penalized before the act itself. Here the Moroccan penal code is inspired by the French penal code in defining the crimes related to forming a gang, mainly article 265 of the 1893 French penal code.

The Moroccan penal code differentiates between a militarized gang and a criminal gang. Article 203 is devoted to the armed gang, and article 293 is devoted to the criminal gang. First, the condition of there being more than one person is included in both types of gangs. Second, the intentional act is also criminalized. Third, both forms are included in dangerous crimes. For the criminal gang and in order to de defined as such, the legislator mentions types of acts considered part of the crime, like rape, kidnapping, killing or theft and robbery, etc.

The Moroccan penal code also differentiates between forming a gang and conspiracy. The conspiracy ${ }^{11}$ crime is the prerogative of the State Police as it involves an attack against the social, economic and political conditions within the country. However, the crime of a criminal gang ${ }^{12}$ is related to public security because it involves an attack on people and private property. We have a lot of examples of these in the modern history of Morocco where the State adapts the penal code according to the political and social circumstances. The best example is the movement in the southern provinces in Morocco in 2010 in which a movement erupted in violence against the Moroccan police when they tried to demolish a camp that was used as a sit-in camp against the socio-economic situation in the city of Laayun. It is known as the Gdeim Izik trial. In this case civilians were judged by a military court in Rabat based on the conspiracy crime allegations.

Although the Tcharmil youth groups do not have any organizational structure, they

\footnotetext{
10 The Moroccan legislator uses the term "ishaba”.

${ }^{11}$ A journalist named Mehdaoui Hamid was accused of conspiracy against the Moroccan state during the Rif Hirak movement.

12 The “Tcharmil” youth gangs in Morocco were accused of forming gangs.
} 
express their frustration with what they describe as a lack of opportunities and respect. These young people have found a new way to get the country's attention: brandishing swords in public and committing petty robberies. Many sport the "faux-hawk" haircut popularized by Portuguese soccer star Cristiano Ronaldo. They have been accused of muggings and robberies.

The third case is the football Ultras accused of hooliganism mainly in the city of Casablanca. Rival Ultras from Rabat and Casablanca confront each other violently using knives. There has even been a death. 21-year-old Hamza Bakkali, a member of the 'Winners', died as a result of riots. These examples show the lack of a social and cultural evolution of the penal code in Morocco. It does not take into consideration the metamorphoses of forms of violence and riots in modern Morocco and mainly in urban cities like Casablanca ${ }^{13}$.

The Moroccan legislator does not only refer to the gang or association but also to being a member of a gang or an association. Any type of help or providing logistics is considered a criminal act. After 2003, the Moroccan justice system amended the penal code to include terrorism as a crime. The terrorist attacks on Casablanca accelerated the passing of the terrorism law ${ }^{14}$.

The diversification of crimes and their complexity obliges the Moroccan legislator to rethink the notion of gang, especially that now we are witnessing the emergence of digital crimes and virtual gangs. The Moroccan penal code takes into consideration new dimensions of gang forming and the nature of the gang; however, the complexity and the blurred aspects between civil disobedience, organized crime and criminal gangs makes the notion of gang in post-Arab Spring a complex issue. Moreover, the transnational dimension ${ }^{15}$ of gangs among the Moroccan diaspora in Western Europe is a multifarious concern that the Moroccan legislator should take into account in dealing with local gangs and their trajectories.

\subsubsection{Tunisia}

The prosecution or arrest of a group of young people in Tunisia can be carried out based on a legal system composed of several legal texts which, for the most part, concern the breach of public order. Since the notion of public order is a vague notion that has not been defined by the legislator, it is essentially based on three criteria: morality, safety and health.

The first text meets the criterion of morality because it is about Article 226 bis of the Tunisian Penal Code that relates to the offense against morality, and states that:

\footnotetext{
${ }^{13}$ The new amendment stipulates that violence during sports events is criminalized (article 308).

14 This is the last amended version of the Penal Code in Morocco. http://adala.justice.gov.ma/production/legislation/fr/Nouveautes/code\%20penal.pdf.

${ }^{15}$ A report published by the United Nations Office on Drugs and Crime on the Globalization of Crime: https://www.unodc.org/documents/southeastasiaandpacific/2010/06/tocta/TOCTA_Report_2010_low_res .pdf
} 
Whoever publicly commits an offense against morality or public morals by gesture or speech or intentionally misleads others in a manner that is offensive to modesty shall be punished by six months' imprisonment and a fine of one thousand dinars.

The same penalties provided for in the preceding paragraph shall be imposed on anyone who publicly draws attention to an opportunity to commit debauchery by means of writings, recordings, audio or visual, electronic or optical messages.

The second text responds to the motive of security and consists of Article 121 of the same code, which relates to rebellion, stating that:

Anyone who provokes rebellion, either by speeches held in public places or meetings, or by placards, posters or printed writings will be punished as if he participated in the rebellion. If the rebellion has not taken place, the provocateur is punished with imprisonment for one year.

In the same vein, Organic Law n ${ }^{\circ} 2015-26$ of 7 August 2015, on the fight against terrorism and the repression of money laundering is used to especially control religious groups of young people.

Finally, we can cite Article 245 of the Criminal Code on defamation which was the most used text to justify the sanctions against groups of young bloggers and which states that:

There is defamation in any allegation or public imputation of a fact that affects the honour or the consideration of a person or a corporate body. Evidence of the defamatory act may be established in the cases provided for in Article 57 of the Penal Code.

It should be noted that for groups of young people under 18 years of age, it is Law $\mathrm{n}^{\circ}$ 9592 of 9 November, 1995, relative to the publication of the child protection code, which is applied. This summarizes the legal framework and the legislation in force in Tunisia on problematic youth groups.

In brief, the Tunisian Penal code uses four main texts with youth street groups according to their ideological tendencies: 1) the Terrorism Act against Religious Groups formed by young people; 2) Article 226 bis against Satanic groups and heavy metal groups; 3) Article 245 related to blogger groups (virtual terrorists); and 4) Article 121 concerning other types of groups such as drug sellers, informal sellers, grafters or hooligans.

\subsubsection{Algeria ${ }^{16}$}

The notion of gang or criminal group organized as a social scourge as it is known in the USA, Latin American countries or in the countries of the former south-eastern European countries, is a phenomenon that is foreign to Algerian society, which explains why it is not included in Algerian law. However, although the idea of a gang or street group does not exist as such, it is substituted by a group of individuals which becomes object of judicial examination from the moment that its members are offenders of a crime against

\footnotetext{
16 The report on youth street groups in Algeria is produced by Beladaci Larbi (Solicitor at the Supreme Court and the State Council) uktyakoub@hotmail.com.
} 
the public thing. In this context, the Algerian penal code deals with two phenomena related to collective violence: mobbing (Criminal Code, Title 1, Chapter II) and the creation of criminal conspiracy (Criminal Code title 1, Chapter VI, Section 1). A crowd or mob is prohibited by law when the individuals who compose it practice violence in any form. That said, practices are considered violent to varying degrees, to the extent that they undermine and are prejudicial to peace, tranquillity, security and public order. There are three main articles in the Algeria Penal Code that govern and repress the various cases of gatherings:

\section{Article 97 of the Algerian Penal Code: The gathering}

For this purpose, Article 97 of the criminal code stipulates:

Any armed or unarmed gathering which may disturb public peace shall be forbidden in a public place.

However, the law provides the following precision, that:

The crowd [group]is considered armed if one of the individuals composing it is carrying an apparent weapon or if several of them carry hidden weapons objects of any kind apparent or concealed having been used as weapons or brought to serve as weapon.

In accordance with the provisions of Article 97, the police officers must intervene according to a dispersion procedure that is deployed in three stages:

1. Announce the presence of the officer of order by a sound or light signal to effectively warn the individuals constituting the crowd.

2. Request the people participating in the crowd to disperse using a loudspeaker or using a sound or light signal of a similar nature to effectively warn the individuals constituting the youth street group.

3. Proceed in the same manner to a second request if the first has had no result.

The Sanctions against the gathering of individuals are recorded in Article 98 and 99 of the penal code.

\section{Article 98 of the Algerian Penal Code}

Any unarmed person who, as part of an armed or non-armed group, has not abandoned it after the first request is punished by imprisonment from two months to one year. Imprisonment is from six months to three years if the unarmed person continues to be part of an armed crowd that has not dispersed before the use of force.

\section{Article 99 of the Algerian Penal Code}

The term of imprisonment can range from six months to three years for anyone in a crowd who has been found carrying an apparent or hidden weapon or any apparent or hidden object used as a weapon or brought to serve as a weapon.

If the crowd is dispersed by force, the imprisonment is from one year to five years.

If the person who is found guilty of any of the offenses provided for in this article is a 
foreigner, the prohibition of the territory may be pronounced against them.

In the case of text governing and repressing the various cases of criminal conspiracy and assistance to criminals:

\section{Article 176 of the Algerian Penal Code}

Any association or agreement, regardless of its duration and the number of its members, formed or established for the purpose of preparing one or more crimes or one or more offenses against persons and property constitutes an association of criminals, which exists due to the sole resolution of acting jointly, and is punishable by at least five years' imprisonment.

The sanctions are described in the Articles 177, 177bis, 177bis 1, 178 of the Algerian Penal Code:

When the prepared offenses are crimes, participation in the criminal conspiracy is punished by imprisonment for five to ten years and a fine of 500,000.00 da to 1,000,000.00 da. When the prepared infractions are offenses, the penalty is imprisonment for two years and a fine of $1,000,000.00$ da to $500,000.00$ da. 


\section{Recommendations for fieldworkers}

This section of the report describes some of the risks of the research activities and some suggestions about the actions that must be taken if they occur. The process of assessing risk can never be codified and described in full because it relies on an understanding of locally contingent patterns of speech and behaviour. Below, we set out instructions that must be followed in situations where danger and risk emerge considering legal codes. However, we also include terms such as "credible threat" as a direct appeal to the expertise of all TRANSGANG researchers. We value and recognise the expertise and experience of local researchers - all of whom are familiar with the language and cultural norms of the countries and communities in which they work. We hope that researchers will draw from their experience and knowledge of the local contexts to assess risks and threats and take appropriate action.

In any case, each researcher has been assigned a local legal advisor to assist them in situations when risks arise. If at any time the researcher feels unsafe, s/he should seek advice from their legal advisor and regional coordinator. In extremis, if an individual researcher perceives an immediate threat to their safety or wellbeing, they should withdraw from the study setting (the neighbourhood in which they have been working). We hope that researchers will draw from their local knowledge when assessing the credibility of a potential risk or threat and decide on the appropriate course of action. But if they remain in any way unsure, they should seek advice from their legal advisor, regional coordinator, ethics manager and TRANSGANG Ethics Advisory Board.

Data will be collected under conditions of confidentiality. This means that under normal circumstances, what participants say during data collection activities will not be shared with anyone outside the research team. However, researchers must understand that confidentiality does not mean secrecy and that there are circumstances in which they may be required to break confidentiality. If at any time, a researcher believes that either a participant or anyone else connected with the study faces a credible threat of physical violence or abuse, or is going to harm someone else, the researcher must put safety before confidentiality and report the incident via the appropriate channel. The circumstances under which confidentiality will be broken must be clearly explained to the participant during the consent meeting. It should be made clear that if the participant is under threat of physical violence or if the researcher has cause to believe the participant is going to harm someone else, the researcher will break confidentiality.

Moreover, as general suggestions, before beginning fieldwork, researchers should nominate a "safe space" where they can go immediately in the event that something goes seriously wrong during the research, such as there is a credible threat to their physical safety. The safe space should be outside the study setting/ neighbourhood where they have been conducting the research and it should have internet and telephone access so that the researcher can contact their ethnographic coordinator, legal advisor, and others who may be able to help. Examples of safe spaces might be the flat or house of a parent 
or friend, a university or other work office, or a similar space that is not known to the research participants.

In the event that a researcher needs to make an urgent report, they should contact their local legal advisor and area coordinator, who will help them resolve the problem and decide on the appropriate course of action, including deciding whether to break confidentiality and make a report to the local authorities. Moreover, all researchers must complete an Ethics Report every two months during the data-collection period. This is a short report on the ongoing ethics and safety of the fieldwork. Researchers should describe any ethical or safety issues that have emerged in the previous two months and what action was taken. The form does not ask for a report on the fieldwork in general and should not include ethnographic information or data. As the report may contain identifiable data such as the names of new participants, it should not be sent via email. Instead, once complete, the researchers should upload the report to the UPF server and notify the Ethics Supervisor that it is complete via email.

In Table 1 we give some examples of possible risks and the type of action that is recommended:

Table 1. Example of risks and actions

\begin{tabular}{|l|l|l|}
\hline \multicolumn{1}{|c|}{ Risk } & \multicolumn{1}{|c|}{ Examples } & \multicolumn{1}{|c|}{ Actions } \\
\hline $\begin{array}{l}\text { Credible threat of physical } \\
\text { violence to the researcher }\end{array}$ & $\begin{array}{l}\text { Someone connected with the research } \\
\text { threatens to kill, hurt, or attack the } \\
\text { researcher and the researcher believes } \\
\text { this threat is credible }\end{array}$ & $\begin{array}{l}\text { Withdraw from the study } \\
\text { setting, Urgent report to } \\
\text { authorities in a Safe place }\end{array}$ \\
\hline $\begin{array}{l}\text { Danger to the researcher } \\
\text { from authorities or } \\
\text { stakeholders }\end{array}$ & $\begin{array}{l}\text { The researcher feels s/he might be } \\
\text { detained, coerced into doing something } \\
\text { against her or his wishes, or otherwise } \\
\text { harmed by the police or someone else } \\
\text { in a position of authority }\end{array}$ & $\begin{array}{l}\text { Withdraw from the study } \\
\text { setting, Urgent report to } \\
\text { country legal advisor and } \\
\text { EAB }\end{array}$ \\
\hline $\begin{array}{l}\text { Credible Threat of Physical } \\
\text { Participant or Participant }\end{array}$ & $\begin{array}{l}\text { The researcher believes that there is a } \\
\text { credible threat of physical violence, } \\
\text { detention, or harm to someone } \\
\text { connected with the research. }\end{array}$ & $\begin{array}{l}\text { Urgent report to country } \\
\text { legal advisor and EAB }\end{array}$ \\
\hline $\begin{array}{l}\text { Major Illegal Activity by } \\
\text { Gang Member }\end{array}$ & $\begin{array}{l}\text { The researcher believes that a } \\
\text { participant is going to harm or do } \\
\text { violence to someone else. }\end{array}$ & $\begin{array}{l}\text { Urgent report to legal } \\
\text { advisor and EAB, } \\
\text { Bimonthly report to } \\
\text { Ethics Manager }\end{array}$ \\
\hline
\end{tabular}




\begin{tabular}{|l|l|l|}
\hline $\begin{array}{l}\text { Coercive, Abusive, or } \\
\text { Inappropriate Behaviour of } \\
\text { Legal Guardians, Tutors, or } \\
\text { Stakeholders }\end{array}$ & $\begin{array}{l}\text { The researcher learns that a legal } \\
\text { guardian, tutor, or someone else in } \\
\text { authority has abused, coerced, or } \\
\text { otherwise harmed a research } \\
\text { participant, or they believe this may } \\
\text { happen in the future }\end{array}$ & $\begin{array}{l}\text { Urgent report to Legal } \\
\text { Advisor and EAB }\end{array}$ \\
\hline Theft of Research Data & $\begin{array}{l}\text { Either identifiable or non-identifiable } \\
\text { data is stolen by someone connected or } \\
\text { not connected with the research }\end{array}$ & $\begin{array}{l}\text { Urgent report to legal } \\
\text { advisor, EAB and local } \\
\text { authorities }\end{array}$ \\
\hline $\begin{array}{l}\text { Health Risks to Participants } \\
\text { (physical or psychological) }\end{array}$ & $\begin{array}{l}\text { The researcher believes a research } \\
\text { participant is going to harm him or } \\
\text { herself. The researcher believes a } \\
\text { research participant requires urgent } \\
\text { medical assistance. }\end{array}$ & $\begin{array}{l}\text { Urgent report to legal } \\
\text { advisor and local } \\
\text { authorities }\end{array}$ \\
\hline $\begin{array}{l}\text { Difficulties in Maintaining } \\
\text { Confidentiality due to } \\
\text { Pressure from Authorities }\end{array}$ & $\begin{array}{l}\text { The police or someone else in a } \\
\text { position of authority asks the } \\
\text { researcher to break confidentiality or } \\
\text { tries to access research data. }\end{array}$ & $\begin{array}{l}\text { Urgent report to legal } \\
\text { advisor, ethics manager, } \\
\text { EAB and PI bimonthly } \\
\text { report }\end{array}$ \\
\hline
\end{tabular}

Source: Own creation 


\section{Conclusions}

In the discourses on gangs in different countries, the media construction of these groups as public enemies generates a situation of insecurity and promotes violence and crime. However, in most cases youth gangs are the result of various processes of social marginalization, which leads young people who grow up in socially disadvantaged families and in marginal neighbourhoods to group together in search of, among other things, an identity. These gangs are not necessarily a problem in themselves, but are the symptom of a society in which youth dissatisfaction is latent. Likewise, the lack of social intervention together with growing social and institutional racism directly influence converting these gangs into a problem. To analyse the phenomenon it is necessary to analyse the public policies and the intervention models that are being carried out. This analysis clashes with that which gives full responsibility for the situation to the young people when they start a path of violence and/or crime.

The results of numerous reports on the subject confirm that despite the increase in criminal activity, gangs cannot be seen as the only parties responsible for urban street crime. These groups do not have the combination of characteristics inherent to criminal organizations, and their purposes are not always exclusively criminal. It is necessary to reverse the approach to break with the stigmatization of these groups of young people in the different communities. In addition, stigmatization has a direct impact on the perception of gangs as a problem and on the degree of exclusion of its members. This directly affects the possibilities of these young people achieving a life that covers their needs, and so they approach crime situations. And not only that, external perception has profound effects on self-perception, so if these young people receive social rejection and racism on a daily basis, they are much more likely to approach situations that they are trying to avoid.

Each country regulates and criminalizes these gangs in a different way, so it is important and necessary to develop a transnational approach and a mechanism for analysing youth gangs in a global way. They can therefore be understood as a joint phenomenon with a connecting thread from which to work, that of marginality, discrimination and lack of opportunities. It is necessary to work on types of mediation to gradually overcome this neoliberal North American centrism that uses the criminal gang model as a general rule for all youth gangs. Therefore, the fact that there are no effective and comprehensive public policies for preventing racism means that the phenomena connected with what it generates are problematized. In the specific case of gangs, it is essential to have programming for understanding diverse cultural identities, and especially curb processes of racism against identities perceived as a threat to the average citizen.

From this position, and leaving aside the criminalizing public discourse, these groups should be thought of as spaces of reception and integration of subjects who suffer some type of exclusion. In this context, it is important to develop less punitive and more inclusive laws. The application of the criminal law thesis of the enemy, consisting of the expression coined by Günther Jakobs in 1985 to refer to the norms that in the German 
Penal Code (Strafgesetzbuch or StGB) criminally sanctioned conducts without them having affected the legal right, is not even the beginning of the execution. These rules do not punish the perpetrator for the crime committed; they punish the person because they are considered dangerous.

In many of the criminal proceedings that affect juvenile gangs there is an expansion of criminal law, only justified to deal with real "threats" or "enemies" of society. The racist construction of the gang imaginary directly affects how different legal operators interpret the actions of gangs. For a young white man from the Salamanca neighbourhood in Madrid, a small-scale trafficking of marijuana intercepted by the police will give him a fright perhaps but in no case will lead him to prison. And yet, for a young Latino, a small marijuana trade may involve the application of exceptional rules as a criminal group or organization, which could multiply the penalty by up to 4 times. The application of laws based on the characteristics of the author is a non-democratic practice that has its roots in the logic of the criminal law of the enemy. Positioning social sectors as an enemy, and even more so if they are young, will only end up radicalizing the processes of violence due to the feelings of legal exclusion it generates, which is linked to the processes of social exclusion for racial motives. 


\section{References}

Aguilar, J. (2019). Las políticas de seguridad en El Salvador 2003-2018. Fundación Heinrich Böll. El Salvador: Equipo Maíz.

Alcaldía de Medellín (2015). Plan Estratégico de Desarrollo Juvenil. Medellín.

Antigone (2015). Seconda casa di reclusione Milano - Bollate. http://www.antigone.it/osservatorio_detenzione/lombardia/11-seconda-casa-di-reclusionemilano-bollate.

Antigone (2017). Ragazzi dentro. Rapporto 2017. http:/www.ragazzidentro.it/it/rapporto-2017/istitutipenali-per-minorenni/.

Antigone (2018). Casa Circondariale di Milano San Vittore. http://www.antigone.it/osservatorio_detenzione/lombardia/98-casa-circondariale-di-milano-sanvittore.

Asamblea Legislativa de El Salvador (2011). Ley de proscripción de maras, pandillas, agrupaciones, asociaciones, y organizaciones de naturaleza criminal. Decreto $\mathrm{N}^{\circ} 458$.

Asamblea Legislativa de El Salvador (2016). Ley especial contra actos de terrorismo.

Camozzi, I., Cherubini, D., Leccardi, C., Rivetti, P., Feixa, C., \& Sánchez García, J. (2014). Youth Cultures: Values, Representations and Social Conditions. SAHWA - Backgroung Papers No. 03-2014. Barcelona.

Campoalegre, R., \& Portieles, I. A. (2013). La delincuencia infanto juvenil: puertas adentro. Documento de archivo del Centro de Investigaciones Psicológicas y Sociológicas. La Habana. Cuba

Canelles, N., Scandroglio, B., \& Lahosa, J. M. (2012). Análisis de las memorias de la Fiscalía general del Estado en relación con las bandas juveniles (2005-2011). Memorias de la Federación Española para la Prevención y la Seguridad Urbana. Madrid. España

Concejo Municipal de Medellín (2014). Acuerdo 019 de 2014 de la Política Pública de Juventudes de Medellín.

Concejo Municipal de Medellín (2006). Acuerdo 84 de 2006: política pública de Protección y Atención integral a la infancia y la adolescencia y se crea el Consejo de Política de Infancia y Adolescencia en la ciudad de Medellín.

Consejo Nacional de Seguridad Ciudadana y Convivencia. Plan El Salvador Seguro. Gobierno de El Salvador.

Departamento Nacional de Política Económica y social, República de Colombia (2011). CONPES 2639: Sistema de Responsabilidad Penal Para Adolescentes - SRPA: Política de Atención al adolescente en conflicto con la Ley. Bogotá., D.C. Colombia.

El Maarouf, M. D., \& Belghazi, T. (2018). The urban and virtual rhetoric of tcharmil: display, violence and resistance. Journal of North African Studies, 23(1-2), 292-310.

Feixa, C. (1998). De jóvenes, bandas y tribus. Barcelona: Ariel.

Feixa, C., \& Canelles, N. (2006). De bandas latinas a asociaciones juveniles: La experiencia de Barcelona. JOVENes. Revista de Estudios Sobre Juventud, 10(24), 40-55

Feixa, C. (2015). Bandas latinas en Cataluña (y más allá). In M. Ledesma (Ed.), Justicia, derecho y sociedad. Debates interdisciplinarios para el análisis de la justicia en Perú. Lima: Centro de Estudios Constitucionales, Tribunal Constitucional de Perú.

Kazyrytski, L. (2016). Las bandas callejeras latinoamericanas en España y el giro punitivo en el tratamiento de su problemática. Indret: Revista para el Análisis del Derecho, 2.

Kazyrytski, L. (2017). Construction of the problem of Latin gangs in Spain and response of the law enforcement system. European Journal on Criminal Policy and Research, 23(3), 301-317. https://doi.org/10.1007/s10610-017-9344-3 
Klein, M. W. (1995). The American Street Gang. Its Nature, Prevalence and Control. Oxford: Oxford University Press.

Ley Estatutaria 1622 (2013). Estatuto de Ciudadanía Juvenil expedido y sancionado en abril del 2103 por la Presidencia de la República.

López Soria, J. (2011). Código Penal Cubano. Ediciones Organización Nacional de Bufetes Colectivos.

Ministerio de Justicia. (2001). Decreto Ley 272 sobre las contravenciones en materia de ordenamiento territorial y de urbanismo.

http://www.cnpc.cult.cu/sites/default/files/DECRETO\%20LEY\%20No.\%20272.pdf.

Ministero della Giustizia (2019). Schede trasparenza istituti penitenziari, $24^{\text {th }}$ of May. https://www.giustizia.it/giustizia/it/mg_2_3_2.page.

Moyersoen, J. (2016). Le bande di giovani latino-americani: dalle origini del fenomeno agli interventi della giustizia minorile a Milano. In Minorigiustizia n. 3, 130-140.

Muñoz, G. (2015). Juvenicidio en Colombia: crímenes de estado y prácticas socialmente aceptables. In J. M. Valenzuela (Ed.), Juvenicidio. Ayotzinapa y las vidas precarias en América Latina y España (pp. 131-164). Barcelona: Ned.

Nateras, A. (2015). El aniquilamiento identitario infanto-juvenil en Centroamérica: el caso de la Mara Salvatrucha (MS-13) y la 'pandilla' del Barrio 18 (B-18). In J. M. Valenzuela (Ed.), Juvenicidio. Ayotzinapa y las vidas precarias en América Latina y España (pp. 99-130). Barcelona: Ned Ediciones.

Observatorio del Bienestar de la Niñez (Colombia Joven, Instituto de Bienestar Familiar, USAID, Organización Internacional para las migraciones) (2015). Adolescentes, Jóvenes y delitos: Elementos para una comprensión de la delincuencia juvenil en Colombia. Bogota D.C. Colombia.

Pañellas, D., Riestra, C., Rodríguez, D., \& Torralbas, J. (2009) Callegeando: Caracterización psicosocial de los jóvenes de la Calle G. Documento de archivo del Centro de Investigaciones Psicológicas y Sociológicas. La Habana. Cuba

Perea, C. M. (2007). Con el diablo adentro: Pandillas, tiempo paralelo y poder. México: Siglo XXI.

Ramos, D., Victor, T., Seidl-de-Moura, M. L., \& Daly, M. (2013). Future Discounting by Slum-Dwelling Youth Versus University Students in Rio de Janeiro. Journal of Research on Adolescence, 23(1), 95-102. https://doi.org/10.1111/j.1532-7795.2012.00796.

Reguillo, R. (2008). Las múltiples fronteras de la violencia: jóvenes latinoamericanos entre la precarización y el desencanto. Pensamiento Iberoamericano, 2(3), 205-225.

Ríos-Peñuela, C., \& Ríos, C. C. (2018). El sistema de responsabilidad penal de adolescentes en Colombia desde un análisis económico del derecho. INCISO, Revista de investigación en derecho y ciencias políticas, 20(1), 146-156.

Tagliafierro, F. (2015). I detenuti per tipologia di reato. Periodo di riferimento: anni 2015-2016 e confronti con anni precedenti. In Rassegna penitenziaria e criminologica, 3, 5-24.

Torres, H., \& Rojas, J. (2015). Tratamiento a la delincuencia juvenil en Colombia en el Sistema de Responsabilidad Penal Adolescente. Verba Iuris, 30, 115-133.

Wolf, S. (2017). Mano Dura. The Politics of Gang Control in El Salvador. Austin, Texas: The University of Texas Press.

Wolffhügel, C. (2017). Instrumentos Internacionales, su armonización, incidencia y aplicación en el Sistema de Responsabilidad Penal para Adolescentes. Bogotá: Escuela Judicial Rodrigo Lara Bonilla. 


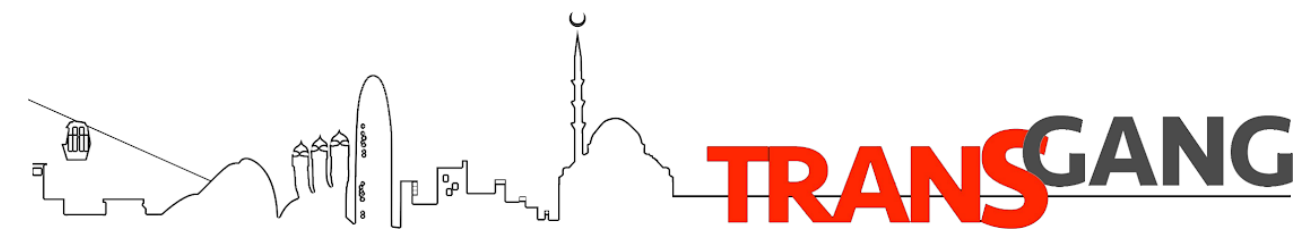

(C) TRANSGANG \& UPF

www.upf.edu/web/transgang

transgang@upf.edu

This project has received funding from the European Research Council (ERC) under the European Union's HORIZON 2020 research and innovation programme under grant agreement No 742705

$$
\begin{array}{r|l}
\mathbf{u} p f . & \begin{array}{l}
\text { Universitat } \\
\text { Pompeu Fabra } \\
\text { Barcelona }
\end{array} \\
\cline { 1 - 2 }
\end{array}
$$

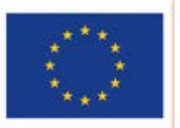

